germ-killing properties be applied to the surface of the ties. Moreover, the organic matter composing the cellular tissue of the wood must be sterilized and rendered inert so that the germs can find no nutrition in them. Theoretically, this can be obtained in a number of ways, but owing to the expense of the different processes it is not always profitable to treat poles and ties.

Most of the ties used by the railroads of the country are treated by the zinc-chloride process, but a few have tried the zinc-creosote and the zinc-tannin processes. On the Chicago \& Eastern Illinois Railroad about 64 per cent of the red oak ties, numbering 860 , 000 , that were put down in 1899 have been taken out to date. These ties were treated by the zinc-tannin process. It is estimated by the engineers of the rail road, however, that all of the ties of red oak would have been out before this had they not been so treated. The railroad owned its own plant for treating the ties, and the cost of the work for each tie can alone determine whether the experiment was profitable. The fact that all subsequent ties are thus treated before laying indicates that the railroad engineers consider treated ties more economical than untreated.

The Pittsburg, Fort Wayne \& Chicago Railway experimented with ties put down in 1892 . A number of white oak ties were used without any treatment, and a similar number of tamaracks and hemlocks treated by the zinc-tannin process. All of these ties have been removed except a few of the hemlocks, and they are to be removed this year. But the fact that the tamaracks and hemlocks lasted as long as the white cak ties is a sufficient proof of the value of the treatment. The ordinary life of the hemlock is much shorter than that of white oak, and its cost in New England is much lower also.

The Atchison, Topeka \& Santa Fe Railway treats its ties with the zinc-tannin process, and the records show that treated hemlock had an average life of 10.71 years, untreated white oak 10.17 years, and treated tamarack 8.84 years. Improvements in the processes of treating ties have been steadily made since these experiments were begun, and the life of the treated ties is thus considered much longer to-day than formerly; but as it takes from ten to fifteen years to secure reliable data it is impossible to give figures that will show the difference between the old and new methods.

The question of using higher-priced chemicals for treating ties and poles has been repeatedly brought forward, and a number of the roads are carrying on experiments on a small scale to ascertain the economy of the different processes. Unless the life of the ties can be increased considerably the extra cost of the chemicals will render the work unprofitable. Each year gained on every tie, however, represents an enormous economy on the large lines. By bringing the average life of the abundant soft woods up to that of the hard woods by using preservatives of a cheap nature, millions of dollars can annually be saved to the railroads of the country. The question of cost of ties for the dif ferent systems is largely a matter of location. In the Southern States, where the long-leaf pine and cypress trees are plentiful, they are used in preference to all other woods for ties, and the important question at issue is to find the most satisfactory and economical method of preserving such soft woods so they will last from ten to fifteen years.

In New England, spruce, hemlock, tamarack, pine, and chestnut trees are most abundantly used, and their relative age of durability is almost in exact proportion to their cost. On the California coast the redwoods are most commonly used, and in the central and prairie most commonly used, and in the central and prairie
States white and red oak, catalpa, tamarack, and hemlock. By treating the softer woods with preservatives most of the roads have succeeded in lengthening their lives so that they can be used almost as satisfactorily as the hard woods. The cultivation of forests of soft woods for railroad ties is an important branch of railroading for the future, for their growth is much more rapid than the hard woods, and if by licing treated with chemicals they perform equally good work, the tie problem will be partly solved. Meanwhile, engineers and chemists are busy testing new processes of treatment, and the difficulties now presented in securing ties that will do service for ten to fifteen years are gradually being eliminated.

\section{FUN WITH THE PHONOGRAPH.}

\section{BY DEXTER W. ALLIs.}

Few owners of the phonograph realize the great versatility of this machine as a source of amusement. By its use the following experiments may be carried out. In addition to the machine itself, a recorder and a few blank records will be needed.

"Speech by Tom Thumb." The machine must be speeded up as high as possible, and the above announcement recorded on a blank in a deep, loud voice. The machine should be quickly slowed down to about eighty revolutions per minute, and the speech or monologue recorded at that speed, care being taken to articulate distinctly. When the blank is full, the reproducer may be substituted for the recorder, and the machine be brought up again to high speed at which the announcement was made. When the record is reproduced at this speed, the result will be the loud voice of the announcement followed by a rapid, pinched-up little voice making the speech.

"A Whistling Duet by John Smith." This startling announcement through the horn would create much surprise.

Put on a blank; and, after the speed is at about 160 revolutions, whistle some popular piece of which you know the second part. When the record is full, set the recorảer back to the beginning again without stopping the machine. When the recording point gets to the commencement of the piece, the first part will sound faintly in the recorder, thus giving the cue an the pitch for the second, which should be recorded not quite so loudly as the first.

Several modifications of this experiment will suggest themselves. The first attempt may not be perfectly successful, but that need not be considered drawback, as a spoiled record can be easily cleane with a rag and a little kerosene. The rubbing shoul be lengthwise of the cylinder till the lines are all re moved, after which a soft cloth is rubbed around the record to give a polish. Hard or gold molded records may also be cleaned in this way, which fact suggests nother amusing trick.

This will call for two records, preferably talking selections, which are exact duplicates. One of these is "doctored" by cleaning off the latter half, the rest being protected by a piece of writing paper wrappe around and secured by an elastic band. On this blank space various remarks should be recorded, which should be very different from those originally there. The good record is to be played through first. While saying that you will repeat it, the second one is quickly substituted in the machine, and of course starts of exactly like the first one. When the "doctored" portion is reached, however, a change will be noticed, but cannot be accounted for by the hearers

By taking two records of entirely different character cutting each in two, and putting on a half of one an a half of the other, we can often jump from the sublime to the ridiculous by quickly flipping the reproducer across the gap, from one to the other. With car the thinner half of one of these records may be slippe halfway on, in a reversed position, and when made to run true, will produce everything backward. A curiou thing about such records is that the voice one hear in the proper direction is instantly recognized whe reversed, but is, of course, unintelligible.

\section{FREDERIC H. BETTS.}

In the death of Mr. Betts, which occurred on the 11th instant in this city, a lawyer of unusual capacity and brilliancy, especially versed in patent law, wa removed from the ranks of those prominent in it practice.

Mr. Betts was born in Newburg, N. Y., in 1843, was graduated from Yale University in 1864, and was admitted to the Bar from Columbia College in 1866 It was shortly after this that he became acquainted with Mr. Alfred E. Beach, then one of the proprietor of the Scientific American, who suggested to Mr. Betts the advisability of taking up the study an practice of the patent law, particularly in its highe aspects before the courts. He followed the suggestion, and soon became prominent and successful in being able clearly to present the salient points of cases committed to his care, During recent years he acted for the American Bell Telephone Company, the Western Union Telegraph Company, the Edison Electric Light Company, and several other prominent corpora tions.

Mr. Betts was always deeply interested in Yale University. He founded the Betts prize in the Yale Law School, and was for a long period lecturer on paten law in the law department of the university. He was also vice-president of the Yale Alumni Association, and in the eighties was connected with several New York citizens' committees and reform organizations. In 1869 he married Miss Louise Holbrook, a daughte of John F. Holbrook, of New York. The widow and three children-two sons and a daughter-survive him. For the last few years Mr. Betts was connected in a legal capacity with the firm of bankers of $\mathrm{J}$. P. Morgan \& Co., and was regarded as one of the most prominent lawyers in New York. The funeral service were held on the 14th instant in St. George's Church of this city, of which Mr. Betts was a vestryman. Many prominent persons were in attendance.

$\mathrm{Mr}$. Betts will be remembered for his sterling ability as an expounder. of the principles of patent law, and their application in the adjudication of difficult and uncertain cases.

In a contribution to the St. Louis Me Revical Review of October 21, Dr. John Zahorsky protests against the fashion of using no cradle, urges the return of the cradle to the nursery and predicts that this usefu article of furniture will be in style again before long. $\mathrm{He}$ cites a number of authorities to prove that "the He cites a number of authorities to prove that "the
soothing, rocking movements of the cradle are posi-

ively beneficial," particularly when infants are peevish. "The cradle is one of the best therapeutic agents for a nervous baby or a sick one," says he. "It is easier on the mother and preferable to the modern succedanea, pacifier, or paregoric."

\title{
SCIENCE NOTES.
}

Camille F"lammarion has been making some experiments at the station for climatologic agriculture of Juvisy, in the suburbs of Paris, to see whether the moon exerts any influence upon the growth of plants, according to the popular opinion. He made different sets of plantings at dates which corresponded to the different phases of the moon, using peas, beets, carrots, potatoes, beans, and many other vegetables of the ordinary kinds. After some experimenting he found that the results which were observed on the growth of the plants were extremely variable, and no fixed rule seemed to govern them. The plants appeared at periods which had no connection with the moon's phases, so that it was impossible to draw any definite conclusions from the first series of experiments. M. Flammarion is to continue his observations on this subject and sooner or later will no doubt have results which will decide this much-disputed point.

Electric traction on the Teltow canal, which is one of the principal canals in Germany, is shortly to be applied on a large scale, in accordance with a proramme formerly decided upon. It will be remembered that a number of experiments with different forms of tractors were made along the canal, and these showed that the electric system offered many practical advan tages. A large central station for supplying the current has already been erected, and is about completed at present. It already contains a 400-horse-power dynamo and engine group and two large steam turbine and dynamo sets of 700 horse-power each. The station will be prepared to furnish current very shortly. The extensive system of locks will first have an electric ystem for operating it. The rails for the electric locomotives have been laid along the canal in the eastern section between Griinau and Britz, on both banks. The overhead wires and the poles are being put in place, so that it will not be long before the locomotives will be ready to haul the canal boats.

Some rather remarkable results which have been obtained in a series of researches upon the radiation given off from polonium are mentioned by $\mathrm{B}$. Walter, a German physicist. According to him, the $\alpha$ rays of polonium under certain conditions give rise to a luminescence of the air when passing through it. In this case there seems to be an emission of a certain kind of radiation which has a very pronounced photochemical effect, one whose properties are to be compared with those of the spectrum which is included between the rays $\lambda=350$ and $\lambda=290$. This radiation is absorbed by a sheet of aluminium 0.0004 inch thick, but it will pass through a plate of glass 0.006 inch thick. This emission seems to be produced especially in the presence of nitrogen. With hydrogen and oxygen the effect is fifty times less intense. Other researches in the same field bring out some of the oxidizing effects caused by bromide of radium. This action is shown when a tube containing bromide of radium is brought near a solution of iodoform in chloroform. A purple color of the solution is observed in the solution even when it is separated from the radium salt by screens of glass, mica, or cardboard. This chemical action does not result from luminous rays but from the special radiations which can pass through the screens. It seems that the $\beta$ and the $y$ rays are the only ones which cause the oxidizing phenomena.

Delegates from all parts of the world attended the recent Congress of World's Economic Expansion which as held at Mons under the patronage of King Leopold II. International expeditions to the North and the South poles were discussed and these projects were ad. hered to by many of the most eminent explorers such as Arktowski, Nordenskjold, Brune, Nansen, Von Drygalski, Racovitza, Charcot, Cook, Peary, and the Duke of Abruzzi. The congress will thus be called upon to lay the foundation for an international association for the study of the polar regions. Besides this important work, the congress made the projects for two international institutions which will be of great value. The first of these is an international Bureau of Ethnography which will collect the documents and specimens fur- 